\title{
THE PECULIARITIES OF SOCIAL WORKERS' PROFESSIONAL TRAINING IN POLAND
}

\section{Kubitskiy Serhii ${ }^{1}$}

DOI: https://doi.org/10.30525/978-9934-571-78-7_21

Abstract. Nowadays, the study and use of foreign experience in the
organization of social education in the light of the ideas of its continuity,
integration and democratization are of particular importance. In this context,
the experience of different countries of the world are of considerable interest
to Ukrainian educators who take interest especially in those of the European
Union countries, where social work and social education have a long history
and rich traditions, where social services are well developed, where original
systems of professional training of the specialists of social work of different levels are created. Hence, the study and creative rethinking of foreign experience will allow the Ukrainian educators not only to learn something new about the activities of their foreign colleagues, but also to rethink their own experience and knowledge, to clear up new perspectives for further development of domestic social practice. In this regard, the analysis of the experience of social workers' professional training in Poland, a member of the European community, being both socially and mentally close to our sociocultural space, is rather relevant. The purpose of the article is to substantiate the essence, content and forms of social workers' professional training in Poland in the context of European experience. The article deals with the peculiarities of social workers' professional training in the Republic of Poland in accordance with the European qualification requirements for mentioned specialists. The specifics of social work as a kind of helping professions are elucidated. It is established that the peculiarity of the professional activities of social workers in Poland stems from the need to combine the community activities with office activities (in state institutions, civic organizations or separate religious/church structure). Moreover, the ratio of these two segments of working time is decided in each case in different ways: most often in social protection institutions the workers spend part of the daily working time in the

${ }^{1}$ Candidate of Pedagogical Sciences, Professor,

Head of the Department of Methods of Education and Management of Educational Institutions,

National University of Life and Environmental Sciences of Ukraine, Ukraine 


\section{Chapter «Pedagogical sciences»}

office; the other part of the daily working time is spent on direct communication with the clients; on the other hand, a part of social workers allocate special days each week for office and client activities. It is proved that the activities of Polish social workers are influenced by two contradictory tendencies, which in a sense counteract each other - the institutionalization of social assistance, on the one hand, and the professionalization of social work - on the other. The changes in the content of professional training of social workers in Poland in connection with their integration into the European Union are substantiated.

\section{Introduction}

At the beginning of the development of an independent state, the socioeconomic situation in Ukraine is marked by significant political, economic, social changes that empress by their scale, dramatic character and depth of contradictions. The crisis situation in the country, the formation of market relations are accompanied by the processes of transformation in education, culture, health care, social security.

Hence, the social worker's professional activities gain a significant importance being aimed at solving people's social problems, the main purpose of which is the organization of professional, purposeful activities in the society through state and non-state social institutions aimed at creating social conditions for full-fledged life and development of various categories of the population. This requires the establishment of an effective system of professional training of social workers who can perform both daily professional tasks and be engaged in research activities in mentioned field.

To date, Ukraine has a certain deficit of highly skilled social work professionals who can professionally accomplish their duty concerning diagnosis and forecasting the social processes, as well as providing preventive, social-therapeutic, psychological, pedagogical and legal assistance to different categories of population. This is largely due to the fact that the professional training of social work specialists began in our country only in the mid-90's when there were significant difficulties due primarily to the lack of practical experience in this field, as well as to the lack of ground scientific and theoretical research in this field and professional training of the specialists for social sphere.

Nowadays, the study and use of foreign experience in the organization of social education in the light of the ideas of its continuity, integration and democratization are of particular importance. 
In this context, the experience of different countries of the world are of considerable interest to Ukrainian educators who take interest especially in those of the European Union countries, where social work and social education have a long history and rich traditions, where social services are well developed, where original systems of professional training of the specialists of social work of different levels are created.

Hence, the study and creative rethinking of foreign experience will allow the Ukrainian educators not only to learn something new about the activities of their foreign colleagues, but also to rethink their own experience and knowledge, to clear up new perspectives for further development of domestic social practice.

In this regard, the analysis of the experience of social workers' professional training in Poland, a member of the European community, being both socially and mentally close to our socio-cultural space, is rather relevant.

The professional training of social workers and the development of their professional competence in recent decades have become the subject of thorough analysis of many scholars (R. Vainola [1], Y. Galaguzov [2], A. Kapska [3], I. Melnichuk [4], V. Polischuk, O. Bartosh-Pichkar, N. Gorishna, G. Leschuk, O. Pryshlyuk [5], etc.).

The profession of a social worker, regardless of the society where his/ her professional skills are realized, requires an interdisciplinary approach, a balanced methodology, and taking into account the experience gained in different countries of the world. The problems of social workers' professional becoming in different countries of the world are presented in scientific works of L. Vinnikova [6], N. Haiduk [7], O. Zagyiko [8], A. Kulikova [9], G. Leschuk [10], and others. At the same time, beyond the attention of many researchers, in our opinion, there are many problems, challenges and risks in the sphere of educating a professionally competent social worker.

So, the purpose of the article is to substantiate the essence, content and forms of social workers' professional training in Poland in the context of European experience.

\section{The essence of social work in the Republic of Poland}

Nowadays, we can find no developed country that can do without social workers trained in the universities and special institutions of higher education. Social workers' calling is to professionally help everyone who needs to solve certain problems in their everyday lives. 


\section{Chapter «Pedagogical sciences»}

First and foremost, the help is to be provided to those who are socially vulnerable: the invalids, seriously and incurably ill persons, elderly people who due to old age, illness, absence of relatives cannot take care of themselves and need attention from social environment, then the orphans and those deprived of parental rights children, as well as homeless children, large families, single disabled citizens, the persons with physical and mental problems, the victims of violence and human trafficking, etc.

The above mentioned categories can be widened with homeless, lowincome persons, the persons just released from places of imprisonment, the refugees, internally displaced persons, etc. The social workers do not only relieve social tensions, they also participate in the development of legislative acts designed to more fully express the interests of different sections of the population.

Social work is inseparable from society and is aimed at all its problematic strata. Therefore, the need for social work will exist as long as there is a society, even at its highest level of development, not to mention the societies in a crisis situation.

In Poland, social work is understood as a professional activity whose purpose is to help people, families, social groups and communities to meet their needs in improving social status as well as in social adaptation, rehabilitation or acquisition of certain skills for self-functioning in a society. Social work contributes to building harmonious social life concerning the relationships within families and social groups [11].

The purpose of the social worker's activities in the Republic of Poland is to help resolve or mitigate social problems, being the source of difficult life situations, poverty or social inequality. Social workers initiate and implement the actions together with people, families and social groups to overcome different problem life situation.

A specialist in social sphere works for the benefit of people, families and social groups who need help. He/she initiates and organizes the actions aimed at counteracting poverty and social inequality of people, families and social groups; he/she plans and acts in order to support people, families and social groups, to interact with communal organizations capable of providing social support for improving the independent functioning of people in a difficult life situation [11].

The circle of social worker's competences outlines: social intervention that provides effective support for people, families and social groups in 
difficult life situation caused by poverty and social inequality, as well as protection of the interests of people, families and social groups in the situations that threat their lives or health, with regard to the elderly, minors, the disabled, single adults and people with mental disorders; initiating and signing a social contract, which involves the active participation of the people in need of assistance; preparation of the plans for assistance and social reintegration, as well as preparation of necessary documents for receiving social assistance; joint planning with people in need of support such actions as individual social employment programs directed at social integration and solving homeless people problems.

The profession of social worker in Poland presupposes:

- carrying out social work with the use of adequate methods and technologies;

- being guided by the principle of the benefit of people, families and social groups;

- respecting the people's and families' dignity and rights for selfrealization;

- resisting inhuman acts and discrimination against people, families or social groups;

- providing the individuals and families with full information on their rights and the forms of assistance they can receive;

- taking steps to obtain and maintain trust and respect from the recipients of social services;

- being responsible for the high quality of the work performed;

- continually improving and raising ones professional level through self-education and participation in the course of postgraduate training;

- helping the promotion of social work as well as forming a positive attitude of society towards the recipients of social services and social assistance;

- analyzing the comments and suggestions of people, families and social groups concerning the work done for them;

- informing the person in need of support about the dangers that may arise in the cases of making or non-making certain decisions (actions) [11].

Besides the standard set of knowledge, skills and competences a social worker in Poland, as evidenced by the scientific research of Polish scientists (M. Duda, K. Wojtanowicz [12]), also requires specific personal characteristics including the internal ethics. In addition, this profession requires constant professional self-improvement and self-evaluation. 


\section{Chapter «Pedagogical sciences»}

In Poland the social workers are understood as qualified specialists of all social services and the persons who work in different social protection institutions throughout the country and form the segment of social services called «helping professions». The professionals associated with these professions in the countries of Europe are often called the helpers; the vast majority of helpers relate to social professions, among which the social worker in the European professional space occupies a dominant position [13, p. 331]. According to Malcolm Pain, there are four types of social services and according to this, the four areas of knowledge and practices correlating with these services:

1) Social justice is the focus of legal science;

2) Education - is the sphere of pedagogy;

3) Health outlines the biomedical branches of science;

4) Social assistance covers the social sciences [13].

At the same time, the affiliation of a specialist to the field of social work and social assistance, as A. Olech states [14], creates some difficulties with the professional identification of mentioned specialists; so, when working in social assistance institution, a social worker may have a more clearly defined professional image than when working in a health institution. O. Olech believes that a social worker is subjected to the phenomenon of «functional generalization», since he/she has to respond to each type of unsatisfied social need (unlike other specialists in the sphere of «man-man»). In this regard, the International Federation of Social Workers offers a very broad definition of social work: «Social work as a profession is introduced in social changes, in solving the problems of human relationships, in strengthening and liberating the persons to achieve their welfare. Guided by the theory of human relationships and social systems, social work is realized where the interactions of personality and environment occur. The fundamentals of social work are the foundations of human rights and social justice» [14].

The activities of social assistance institutions are often considered in the context of social work, and therefore social workers are defined as professionals able to provide assistance to people in these institutions [15, p. 12].

At the same time, at the local level, social workers are often understood in a simpler way taking into account their function of providing direct financial assistance; in this regard, the image of a social worker in Poland is rather blurry, far from how it is covered the theory of social work and teaching disciplines related to professional training of social workers in the institutions of higher learning of this country. 


\section{Specificity of the professional activities of social workers in Poland}

The peculiarity of the professional activities of social workers in Poland stems from the need to combine community activity with office activities, and these offices are often placed in a government institution, a public organization or a separate religious (often church) structure. The ratio of these two segments of working time is decided in each case in different ways:

- most often in social protection institutions the workers spend part of the daily working time in the office;

- the other part of the daily working time is spent on direct communication with the clients; on the other hand, a part of social workers allocate special days each week for office and client activities [15, p. 12].

Herewith, the statistics show that in all cases, the activities in the community take significantly more time than the office work of social workers. This, for example, greatly distinguishes the work of a social worker from the work of a doctor who takes patients mainly in his/her doctor's office.

Compared with other socially oriented professions (not only with the profession of a doctor), a social worker, according to Polish scientists (T. Kazmierchak [17], M. Bocheńska-Seweryn, K. Frysztacki, K. Kluzowa [18], A. Olech [19], B. Bąbska [20] et al.) is rather underestimated and is often considered to be «an employee of everything and nothing», since the complex of social problems is quite large, and since the number and quality of the indicators of risk groups constantly grow up.

The analysis of scientific literature enables to conclude that the activities of the Polish social worker are influenced by two quite contradictory trends that, in a sense, are opposed to each other: the institutionalization of social assistance, on the one hand, and the professionalization of social work, on the other.

\section{History of introduction of social work in Poland}

The introduction of systematic professional training of social workers in Poland is traditionally associated with the Council of Europe directive $89 \backslash 48 \backslash$ EWG, which stipulated the mutual recognition of the diplomas in higher education, including those of social specialists.

And next year, the social work was recognized in Poland as a professional activity, which had to be confirmed in all countries of the European Union, starting from 2005. However, this does not mean that social work as a profession did not exist on Polish territory before: in 1925, 
in Warsaw, there were implemented the courses in social and educational activities presupposing two specialties: the organizer of cultural life and social care, as well as the organizer of social care for children and youth [20, p. 281]. Helena Radlińska, the founder and mastermind of this educational institution, put forward the fundamentals of the concept concerning «growing and multiplying human forces, improving them and organizing joint activities for the good of people» [22, p. 335].

In post-war time, in Poland the social work as a branch of scientific knowledge, unlike on Soviet territories, continued to develop until 1950; then in Poland the «principle of social justice» was proclaimed, and social workers were outlawed as a remnant of capitalism.

Taking advantage of «Khrushchev thaw» in the Soviet Union, and following the scientific works of Helena Radlińska, Polish scholars and educators restored the search for technologies of social welfare in the 60's in the form of two-year schools for social workers, and since 1966 public schools of social work were grounded [22, p. 38].

Structurally, the system of social care was subject to health care, which severely restricted the possibilities of psychological and pedagogical developments in this field and determined the content of professional training of pertinent specialists. Instead, in 1990 Poland (in its first revision) adopted the Law on Social Assistance, which defined the leading functions of social workers and the requirements for their qualification, such as:

1) compulsory completion of studies at appropriate studios - the schools of social workers or the institutions of higher education in the field of «social work», «social policy», «re-socialization», «sociology», «pedagogy», «psychology» and other related professions;

2) the ability to create conditions helping the functioning of the individuals and families in the social environment;

3 ) the availability of a set of professional knowledge, skills, competences and personal characteristics that meet the qualifications in the field of providing social assistance.

\section{Training of social workers in the Republic of Poland}

Since 1993, social workers in the Republic of Poland have been trained according to new programs based on interdisciplinary approach to training the social workers in social work schools. To this end, such subjects as sociology, social pedagogy, social policy, social medicine, psychology, 
law, management, etc. were introduced into the curricula. According to J. Szmagalski's estimation, industrial practice, which took about $30 \%$ of study time, was combined with practical classes in social work schools, which contributed to the formation of professional competences and practice-oriented skills in the prospective social workers.

At the end of the twentieth century, the prerogative of social workers' professional training at the level of social work schools was given to the authorities of local self-government.

This step meant a conceptual restructuring the entire system of social care, prevention and assistance, which ever more localized at the level of the gmina (small districts) and counties (areas with larger territories that unite gmina) [22, p. 39].

At the same time, a number of electives, additional specializations and training directions were introduced in the higher education system, targeting those seeking social professions at the profession of social worker with higher education.

The new Social Assistance Act (2004) put even greater pressure on local self-government bodies presupposing their participation in providing social care and assistance depending on regional social conditions and the availability of appropriate risk groups that required the intervention of a social worker (in this respect it is necessary to pay attention to the reasons for which social assistance is provided:

1) poverty;

2) orphan hood;

3) homelessness;

4) unemployment;

5) disability;

6) long-term or severe illness;

7) domestic violence;

8) protection of the victims of human trafficking;

9) protection of maternity and the families with many children;

11) integration of foreigners;

12) adaptation to society of the persons released from the places of imprisonment;

13) alcoholism and drug addiction;

14) accidental events and crisis situations;

15) natural or ecological catastrophe). 
According to this Law, appropriate changes were to be realized in the content of professional training of social workers - both in the schools of social work and in the institutes of higher education, which trained the specialists for social sphere. The qualification requirements for social workers stemmed from their ability to perform the following tasks:

- providing the individuals and risk groups with social support in difficult living conditions;

- providing the representatives of risk groups with the conditions meeting the level of human dignity;

- professional assistance to the families with social pathologies;

- providing the individuals and families with the opportunity to solve their own social problems;

- promoting integration of socially excluded persons into social environment [12].

Further changes in the content of professional training of social workers in the Republic of Poland were determined by two main factors:

1) the entry of the Polish system of higher and secondary specialized education into the European space in accordance with the Bologna Declaration;

2) the decision of the European Union on the introduction of licentiate (baccalaureate) studies as a minimum term of study, which may be the basis for mutual recognition of the diplomas in all the countries of the Union [23].

In 2007, amendments to the «Law on Social Assistance» were adopted in Poland, according to which the requirements for the qualification of social workers according to the European standards were put into practice. According to these changes, the social worker should have met one of the three following positions:

1) to receive a diploma of the collegiums of social services;

2) to complete professional training in higher education in the specialty «social work»;

3) by December 2013, to complete higher education in such specialties as «pedagogy», «social pedagogy», «political science», «social policy», «psychology», «sociology», «family science» [24].

Subsequently, the colleges of social work were gradually abolished as not meeting the basic principles of the Bologna Declaration; besides, in a 


\section{Kubitskiy Serhii}

few years certain related professions were declared that did not give the right to be a social worker.

Thus, social workers in Poland began to train exclusively in the higher educational establishments in the specialty «social work» (bachelor), when the professional disciplines should have been not less than 330 hours, and internship - not less than 240 hours for the bachelor's degree.

In the process of passing the internship the students should acquire the following knowledge: the specifics of the activities of social welfare institutions, the institutions and organizations that provide social assistance to the individuals and families in need, in particular:

a) the structure and organization of such institutions;

b) the types of social services;

c) the demographic, economic, psychological and social characteristics and needs of social service clients;

d) effectiveness of social services and such skills: 1) to interact with employees of a social institution; 2) to establish contacts with the clients of social service; 3 ) to identify the problems of social service clients at micro, me so, and macro levels.

The basic skill after passing professional practice should be students' ability to gather materials necessary for preparing and implementing social projects [16].

In the process of professional training, the social workers acquire the competencies needed to understand and interpret the assistance processes, social integration and activation of the individuals and groups being in the risk of isolation in changing circumstances, and the professional skills necessary to carry out specialized activities in supporting the social institutions, in particular:

- the proper establishment of interpersonal contacts and recognition of the status of people and families who use social assistance;

- defining the objectives of assistance and analysis of the determinants for people and groups in difficult situations;

- planning the forms of assistance and the application of effective ways and methods of social work;

- cooperation between institutions and professionals in the process of providing effective assistance;

- monitoring and evaluating the measures taken;

- projecting the social events; 
- improving the organization of own work;

- popularization of the goals of social assistance and work;

- prevention of psychological burnout;

- application of professional ethics [16].

The professional training of social workers during this period was actively supported by the theoreticians and practical educators working in the sphere of lifelong education. In this respect the question arose about social workers' professional self-improvement, being a European requirement, implemented in Polish conditions. This made it possible to organize post-graduate courses and re-training of social workers at the level of voivodships (since 2004 - also counties).

Currently, these special courses are traditionally organized at family care centers in the counties, using two leading concepts:

- improvement of social workers' professional skills and deepening their general professional knowledge;

- the expansion of highly specialized knowledge of social workers among specific social groups needing social support in particular regions [20, p. 291].

Throughout the 90s of the XXth century - 10s of the XXIst century, the professional training of social workers in Poland took place in line with European educational standards reflected in a special document entitled «Global Standards for Education and Training in Social Work» [25], according to which the Polish educational institutions involved in the professional training of social workers had to meet the following requirements:

1) the condition for successful professional training of social workers is the possibility of influencing the content and methods of the specified training by the representative (including non-governmental) organizations of social workers;

2) the professional training of social workers, carried out at the level of bachelor's and master's degrees, should take place with the participation of both the teachers and practicing social workers, as well as the consumers of social services;

3) the teachers who train the social worker practice should have practical experience in social assistance;

4) NGOs that train social workers should have sustained educational and technological links with social institutions [26]. 


\section{Kubitskiy Serhii}

\section{Conclusions}

Thus, we have analyzed the peculiarities of social workers' professional training in the Republic of Poland in accordance with the European requirements for the qualification of these professionals, according to which the specifics of social work as a kind of helping professions are clarified.

It is determined that in Poland, social work is understood as a professional activity whose purpose is to help people, families, social groups and communities to meet their needs in improving social status as well as in social adaptation, rehabilitation or acquisition of certain skills for selffunctioning in a society. Social work contributes to building harmonious social life concerning the relationships within families and social groups.

The purpose of the social worker's activities in the Republic of Poland is to help resolve or mitigate social problems, being the source of difficult life situations, poverty or social inequality. Social workers initiate and implement the actions together with people, families and social groups to overcome different problem life situation.

It is established that the peculiarity of the professional activities of social workers in Poland stems from the need to combine the community activities with office activities (state institutions, civic organizations or separate religious (and church) structures).

It is proved that the activities of a Polish social worker are influenced by two quite contradictory tendencies, which in a sense counteract each other - the institutionalization of social assistance, on the one hand, and the professionalization of social work - on the other.

The changes in the content of professional training of social workers in Poland in connection with integrating into the European Union are substantiated.

The prospect of further research is connected with the analysis of the content of professional training of social workers in the Republic of Poland in accordance with the requirements of the Bologna Process.

\section{References:}

1. Vainola, R. Kh. (2008). Personality development of future social Teacher is in the process of professional preparation. Zaporizhzhia. (in Ukrainian)

2. Galaguzova, Yu. N. (2001). Theory and practice of system training of social educators. Moskva. (in Russian)

3. Kapska, A. Y. Some aspects of training social workers and social workers. URL: http://www.nbuv.gov.ua/old_jrn/Soc_Gum/Vgnpu_ped/2010_15_2/V15_2_12_16.pdf 


\section{Chapter «Pedagogical sciences»}

4. Melnychuk, I. M. (2011). Theory and methods of training future social workers by means of interactive technologies in higher education. Ternopil. (in Ukrainian)

5. Bartosh-Pichkar, O. P., Gopishna, N. M., Polishchuk, V. A. et al in Nychkalo, N. H. (2010). Social Work: A Textbook. Ternopil: VAT «TVPK Zbruch». (in Ukrainian)

6. Vinnikova, L. V. (2003). The system of social workers in US universities. Lugansk. (in Ukrainian)

7. Gaiduk, N. P. (2005). Training of social workers to mediation (based on the US and Canada). Kyiv. (in Ukrainian)

8. Zagaiko, O.V. (2008). Preparing social workers for middle, secondary schools UK. Kharkiv. (in Ukrainian)

9. Kulikova, A. Ye. (2009). Training of social workers to work with children and young people in higher education Sweden. Lugansk. (in Ukrainian)

10. Leshchuk, G. V. (2009). The system of professional training of social services in France. Ternopil. (in Ukrainian)

11. Social work is in Poland. URL: https://stud.com.ua/65173/sotsiologiya/ sotsialna_robota_polschi

12. Duda M. Korzyści i niebiespieczeństwa wynikające z permanentnego szkolenia pracowników socjalnych w Polsce / M. Duda, K. Wojtanowicz // Nová sociálna edukacjá ćloveka IV: Medzinarodná interdisciplinárna vedecká konferencia. URL: file://C:/Documents\%20and\%20Settings/User\%B9/Duda_Wojtanowicz.pdf

13. Payne M. What is Professional Social Work? Bristol: Policy Press, 2008. 122 p.

14. Olech O. Praca socjalna a inne profesje: punkty styczne i rozłączne. Pracownicy socjalni i praca socjalna w Polsce. Między służbą społeczną a urzędem / Pod red. M. Rymszy. Warszawa: Instztut spraw publicznych, 2012. S. 331-352.

15. Materiały International Federation of Social Workers. URL: http://www.ifsw.org

16. Pracownicy socjalni i praca socjalna w Polsce. Między służbą społeczną a urzędem / Pod red. M. Rymszy. Warszawa: Instytut spraw publicznych, 2012. 400 s.

17. Kaźmierczak T. Praca socjalna. Między upośledzeniem społecznym a obywatelskością. Katowice: Wydawnictwo Naukowe «Śląsk», 2006. 388 s.

18. Bocheńska-Seweryn M. Wypisy $\mathrm{z}$ wybranych zagadnień pracy socjalnej / Bocheńska-Seweryn M., Frysztacki K., Kluzowa K. (red.). - Kraków: Instytut Socjologii Uniwersytetu Jagiellońskiego, 2000. $196 \mathrm{~s}$.

19. Olech A. Etos zawodowy pracowników socjalnych. Wartości, normy, dylematy etyczne. Katowice: Wydawnictwo Naukowe «Śląsk», 2006.

20. Bąbska B. Pomoc społeczna i praca socjalna w Polsce po 1989 roku. Ośrodek pomocy i aktywności społecznej - renesans pracy środowiskowej: P. Jordan (red.). Warszawa: Stowarzyszenie Centrum Wspierania Aktywności Lokalnej CAL, 2007. S. 38-49.

21. Szmagalski J. Kształcenie do pracy socjalnej w Polsce po 1989 roku. Pracownicy socjalni i praca socjalna w Polsce. Między służbą społeczną a urzędem / Pod red. M.Rymszy. Warszawa: Instztut spraw publicznych, 2012. S. 279-298.

22. Radlińska H. Ptdagogika społeczna. Wrocław: Ossolineum, 1961. $418 \mathrm{~s}$.

23. Biederman V. Problemy kształcenia pracowników socjalnych. Praca socjalna służbą człowiekowi: L. Malinowski, M. Orłowska (red.). Warszawa: Wydawnictwo Akademickie «Żak», 1998. S. 12-36. 


\section{Kubitskiy Serhii}

24. Dyrektywa 2005/36/WE Parlamentu Europejskiego i Rady z dnia 7 września 2005 roku w sprawie uznawania kwalifikacji zawodowych (Dz.U. UE L 255/22, PL, 30 września 2005 roku, art. 2-4, 12-14, pkt 9-18).

25. Ustawa z dnia 16 lutego 2007 roku o zmianie ustawy o pomocy społecznej (Dz.U. z 2007 r., Nr 48, poz. 320).

26. Globalne standardy edukacji i szkolenia w zakresie pracy socjalnej // Praca Socjalna. 2005, Nr 3. S. 103-135.

27. Czy podejście aktywizujące ma szansę? Pracownicy socjalni i praca socjalna w Polsce 20 lat po reformie systemu pomocy społecznej / M. Rymsza (red.). Warszawa: Instytut Spraw Publicznych, 2011.312 s. 